\title{
Texture analysis of transcranial sonographic images for Parkinson disease diagnostics
}

\author{
A. Sakalauskas ${ }^{1}$, A. Lukoševičius ${ }^{1}$, K. Laučkaitè ${ }^{2}$ \\ ${ }^{I}$ Biomedical engineering institute at Kaunas University of Technology \\ Studentu str. 65, Kaunas LT-51359 Lithuania \\ Phone: +370 37 407119; Email: sakalauskas.andrius@yahoo.com, arunas.lukosevicius@ktu.lt \\ ${ }^{2}$ Lithuanian University of Health Sciences, Clinic of Neurology
}

Eiveniu str. 2, Kaunas LT-50009 Lithuania

Email: kristinalauckaite@hotmail.com

\begin{abstract}
Parkinson disease (PD) diagnostics based on transcranial sonography (TCS) images are quite subjective and dependent on competence of physician due to low quality of acquired images. The aim of this study is to evaluate potentiality of textural analysis of TCS images for separation between images obtained from healthy and PD affected people. Closer to scanning probe half of midbrain was manually selected as region of interest (ROI) for texture analysis in TCS image. Four hundred thirteen texture features of ROI (110 subjects) were calculated and used for classification during this study. Sequential feature selection method was applied in order to find optimal subset of features for such classification task. Linear support vector machine (SVM) classifier was used for determination of the optimal number of features for new subset.

The classification rate $78.18 \%$ was obtained using the calculated texture features. It was concluded that discrimination power of these texture features is directly dependent on the image quality.
\end{abstract}

Keywords: texture analysis, multiple feature extraction, sequential feature selection, support vector machines, classification rate.

\section{Introduction}

Transcranial B - mode sonography was proposed as a diagnostic technique for supporting the clinical diagnosis of Parkinson disease (PD) in 1995 by Becker et al. [1]. Recently this examination found early applications in a clinical diagnostics of PD and other neurological disorders. It is assumed that especially early stages of PD can be diagnosed using the transcranial sonography (TCS) [2]. A butterfly-shaped midbrain and the small area of midbrain, called mesencephalic substantia nigra ( $\mathrm{SN}$ ) is a small brain region where neurotransmitter dopamine is produced. This is a region of interest (ROI) during this examination (an example of TCS image and ROI is shown in Fig. 1). The confirmation of PD diagnosis is based on increased echogenicity in the SN area in the obtained TCS images. Several researches [1-3] had showed that size of the echogenic SN area of PD affected patients was significantly larger than for healthy persons. Authors recommend to diagnose neurological disorder when the size of the $\mathrm{SN}$ area exceeds $0.20 \mathrm{~cm}^{2}\left(S_{S N}>0.20 \mathrm{~cm}^{2}\right)$ [3].

Ultrasonic examination is quick to do, relatively cheap and harmless to a patient, but one of the main drawbacks of TCS examination is a poor image quality and this makes the diagnostic of neurological disorders quite subjective. The structures of interest are hardly recognizable in the obtained TCS images and only an experienced physician can identify and correctly interpret the corresponding brain structures. The quality of images is poor because the examination is performed through a relatively thin preauricular temporal bone, therefore propagation of ultrasound waves are highly affected by attenuation and refraction of nonhomogeneous layers of the skull bone. Also due to strongly a frequency - dependent skull bone attenuation and internal reflection, scanning is performed in a relatively low frequency range $(1-4 \mathrm{MHz})$, thus causing the limited spatial resolution of TCS images. Approximately $10 \%$ of population has an insufficient temporal bone acoustic window, therefore the obtained TCS images are inappropriate for a neurological evaluation.

The neurological evaluation is performed by measuring the size of SN area in the obtained image of a cross-section of midbrain. During scanning the physician manually outlines the SN area after acquisition of TCS image. Such marking is rather approximate, because in many cases there is no clearly seen SN area (blurred or missing boundaries), due to a poor quality of TCS images. Therefore the neurosonologyst who performs evaluation usually follows own intuition implying marking the possible, most probable $\mathrm{SN}$ area, regarding to a prior anatomical knowledge about location of the $\mathrm{SN}$ area respective to midbrain location. Visual evaluation of TCS images with the marked ROI showed that frequently there is no hyperechogenicity in all pixels of area outlined by the physician. Therefore such evaluation seems quite subjective.

In recent years the texture analysis of ultrasonic images was discovered as an effective toll for a tissue characterization and for classification purposes. Few earlier attempts to employ the textural analysis of TCS 
images for separation of images obtained examining the PD affected and healthy people could be found in literature [4 - 6]. C. Kier et al. [4] selected and tried geometrical moments (moment of inertia and seven $\mathrm{Hu}$ moments) for such classification task. The results showed that the moment of inertia and Hul moment could be promising image characteristics. L. Chen $[5,6]$ combined these geometrical moments with statistical moments (mean, variance, entropy, skewness and etc.) and texture features extracted using the Gabor filter into a set of feature vectors, with aim to select the best multiple feature subset for classification. Authors demonstrated that $96.15 \%$ classification rate could be obtained (specificity - 94.44\% and sensitivity - 97.62) using a subset consisting of five features (Hu1 moment, average contrast and three features extracted using Gabor filter). These results are really impressive because approximately $90 \%$ classification rate is obtained when evaluation is performed manually marking the $\mathrm{SN}$ area.

The aim of this study is to evaluate potentiality of the textural analysis of TCS images for separation between TCS images of healthy and PD affected people trying to combine image characteristics reported before [4-6] with a new set of texture features.

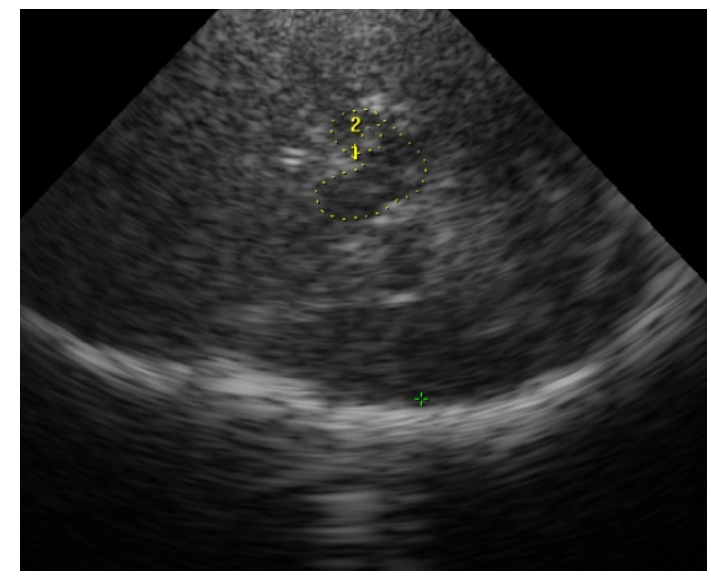

Fig.1. TCS image: areas of midbrain (No. 1) and SN (No. 2) marked by dotted line

\section{Materials \& methods}

One hundred ten subjects were examined during our research, 61 (age of 63.39 \pm 9.89 , range $40-80$ years) of them had clinical PD diagnosis, other 49 (age of $58.23 \pm 18.19$, range $24-81$ years) - healthy subjects. The study was conducted in accordance with Declaration of Helsinki and with the approval from the local ethics committee. This study was carried out at Neurology clinic at Lithuanian University of Health Sciences. Scanning was performed using PA2-5 wide band phased array sector transducer $\left(f_{0}=1.4 \mathrm{MHz}\right.$, band with: $1.3-4 \mathrm{MHz}$, footprint $20 \times 14 \mathrm{~mm}(128$ elements $))$ driven by the ultrasound scanner Voluson730 (General Electric Medical Systems). All subjects were examined by the same experienced physician sonographer. The scanning was performed at 18.5 depth, the scanning parameters (TGC curve, gain, zoom) was adapted in order to get the best possible image by a physician performing scanning. All subjects were scanned through left and right temporal bones of the head.

The obtained TCS images were prepared for the texture analysis. Histological changes of brain structures occurs in the both sides of mesencephalon when PD affects, therefore closer to the scanning probe half of midbrain was selected as ROI in TCS image for texture analysis, because there a better resolution is obtained. Evaluation of both sides of midbrain from one TCS image would be ambiguous, due to losses of contrast, resolution and SNR with increase of a scanning depth. The upper half of the midbrain was manually outlined by the physician in all TCS images. An example of the selected ROI in TCS image is shown in Fig.2. Size of analyzed areas was approximately $2.5 \mathrm{~cm}^{2}$ (1500 pixels).

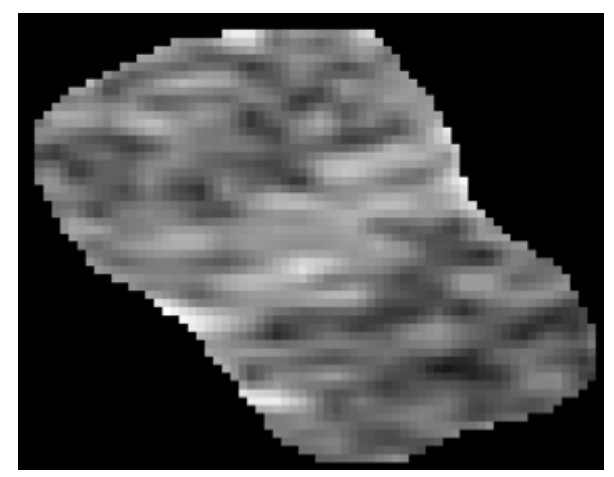

Fig. 2. Manually outlined ROI in TCS image for texture analysis

The texture analysis of TCS images was performed calculating parameters of ROI reported in $[4-6]$, furthermore MaZda free software package was used. MaZda is a computer program for calculation of texture parameters (features) in digitized images [7, 8]. Default options of MaZda software were used during analysis. The list of features used for analysis is summarized in Table 1.

Four hundred thirteen different features characterizing ROI of TCS image were calculated. In order to reduce dimensionality of data non-informative features were filtered using estimate of statistical significance: $t$-test was applied for each feature separately as a measure of feature's efficiency in separating groups of interest [14]. The estimated $p$-value was used as a threshold for filtering features, which hasn't had strong power of discrimination. Relationship between each feature in a primary set and its $p$-value is shown in Fig. 3.

It should be mentioned that approximately $20 \%$ of the calculated features have lower than $0.1 p$-values, therefore these features were chosen as appropriate for classification. Set of features was reduced in size and sorted according to the calculated $p$-values (starting from lowest value). The optimal subset of features was established using sequential feature selection method (SFS). The goal of SFS is to find such subset of features in a primary set that optimizes an objective function: 
Table 1. List of features used for texture analysis of TCS images

\begin{tabular}{|c|c|c|c|}
\hline Feature group & Main features & $\begin{array}{l}\text { Number of } \\
\text { features }\end{array}$ & Reference \\
\hline Statistical moments & Homogeneity, Correlation, Autocorrelation, Entropy etc. & 22 & {$[11-13]$} \\
\hline Gabor texture features & $\begin{array}{l}\text { Mean and standard deviation of magnitude of the Gabor transform } \\
\text { coefficients }\end{array}$ & 30 & {$[5,6,9]$} \\
\hline MaZda texture features & $\begin{array}{l}\text { Histogram features, gradient features, Coocurrence matrix, Haar wavelet } \\
\text { etc. }\end{array}$ & 352 & {$[7,8,10]$} \\
\hline Geometrical moments & Hu moments, moment of inertia & 8 & {$[4]$} \\
\hline Measurements of SN area & Size of outlined SN area & 1 & $*$ \\
\hline
\end{tabular}

* Results of measurement of SN area were obtained during our study by professional physician

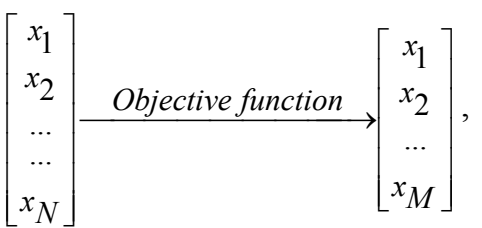

where $x$ is the feature, $N$ is the number of features in primary set, $M$ is the number of the selected features in a subset, $M<N$. Method similar to reported in [6] was applied for finding an optimal subset in our approach. The filtered and sorted set of features were used for classification. Linear support vector machine (SVM) classifier was used for selection of features in SFS. The optimal number of features was found analyzing dependence between misclassification error (MCE) of SVM classification and the number of features used for classification as an objective function. A local minimum of MCE in this dependency was used as a stopping criterion for establishment of the subset of features which are optimal for classification. The MCE estimate was calculated dividing the number of misclassified images by the number of all images. Official clinical diagnosis was considered as a gold standard for finding number of misclassifications.

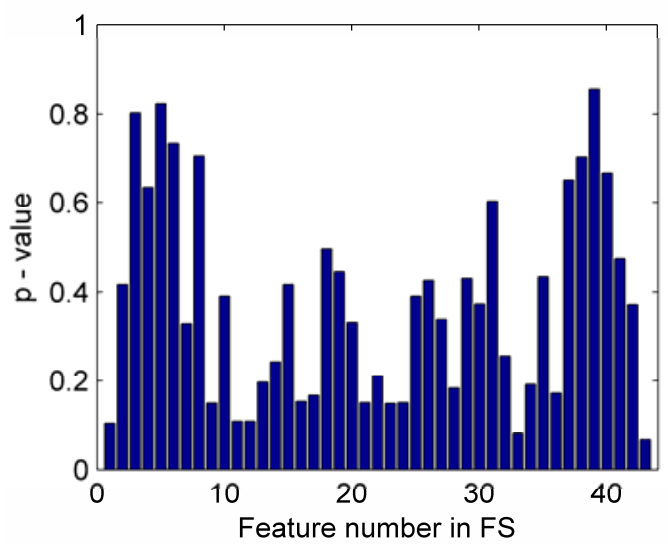

Fig. 3. Results of $t$-test applied on first 45 features of primary set (FS)

The linear SVM classification is based on the assumption that the data, represented as points, could be separated by a linear hyperplane. The aim is to find the optimal separating hyperplane. Principle of SVM could be explained solving the problem of separating the set of training vectors $x_{i}$ belonging to two separate classes $y_{i}$ $\in\{-1,1\}: \quad D=\left\{\left(x_{i}, y_{i}\right) \mid x_{i} \in R^{n}, y_{i} \in\{-1,1\}\right\}_{i=1}^{n}$, with a hyperplane: $\mathbf{w} \cdot x+b=0$, where the $y_{i}$ is the indicator of class to which the point $x_{i}$ belongs, $x-n$-dimensional vector, $\boldsymbol{w}$ is the normal vector to hyperplane. The set of vectors is optimally separated by the hyperplane if it is separated without error and the distance between the closest vector to the hyperplane is maximal [15]. If the training data points are linearly separable, the two hyperplanes of the margin could be selected in a way that there are no points between them and also the distance between them must be maximized. The distance between these two hyperplanes is $2 /\|\mathbf{w}\|$, so the goal is to minimize $\|\boldsymbol{w}\|^{2}$ [16]. Constraint must be added for each $i$ for prevention of data points from falling into the margin:

$$
\left\{\begin{array}{l}
\mathbf{w} \cdot x_{i}+b \geq 1, \text { for } x_{i} \text { of the first class; } \\
\mathbf{w} \cdot x_{i}+b \leq-1, \text { for } x_{i} \text { of the second. }
\end{array}\right.
$$

Eq. 2 could be rewritten as:

$$
y_{i}\left(\mathbf{w} \cdot x_{i}+b\right) \geq 1, \forall 1 \leq i \leq n .
$$

Finding the maximum margin can be formulated as an optimization problem: to minimize $\|\mathbf{w}\|^{2}$, subject to constraint (3). Since $\|\mathbf{w}\|^{2}$ is convex, minimizing it under linear constraints can be achieved with non-negative Lagrange multipliers [16] $\alpha_{i}, i=1 \ldots \mathrm{M}$ :

$$
\max _{\alpha} L(\alpha)=\sum_{i=1}^{M} \alpha_{i}-\frac{1}{2} \sum_{i=1}^{M} \sum_{j=1}^{M} \alpha_{i} \alpha_{j} y_{i} y_{j} K\left(x_{i}, x_{j}\right)
$$

where $K$ is the Mercer kernel function. Decision function could be expressed from the objective function (4):

$$
y=\operatorname{sgn}\left(\sum_{i \in S} \alpha_{i} y_{i} K\left(x_{i}, x\right)+b\right),
$$

where $S$ is the index set of all support vectors. Generally the task of SVM is to separate two classes by a function which is induced from available examples and to produce a classifier that will work well on unseen examples [15].

All TCS images were separated into two equal groups. The first one was used for cross-validation and training of the SVM classifier, the second - for SFS and testing of the formed subset for classification of images. Evaluation of efficiency of the formed subset was performed using the same SVM classifier. It should be mentioned that some 
features in the formed subset are highly correlated to each other and do not carry a new information about the texture, so correlation between these features was calculated, and non-informative features were removed from the formed subset. Structure of the proposed feature extraction method for classification of TCS images is shown in Fig. 4.

\section{Results}

Various combinations of feature sets were tested for classification of TCS images. Two types of SFS method were applied for selection of features: forward and backward. The main difference of these two methods is that the forward SFS begins having an empty subset and the features are included starting from the most appropriate, while the backward SFS is performed removing features from the primary set. Classification rate (opposite metrics to MCE), sensitivity and specificity were calculated in order to evaluate discrimination power of the subset of selected features.

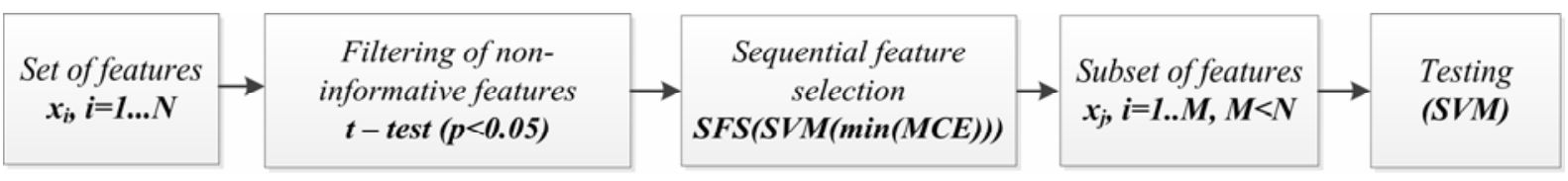

Fig.4. Structure of proposed feature extraction method for classification of TCS images

Results of size measurements of manually outlined SN area were used for classification of TCS images, using recommended cut-off value $0.20 \mathrm{~cm}^{2}$. The classification rate $85.58 \%$ (sensitivity $94.00 \%$, specificity $78.68 \%$ ) was calculated as a result to be compared with before testing subsets of the selected features for classification of TCS images. The results of classification of TCS images using subsets of features selected using SFS from different primary sets are presented in Table 2 .

Table 2. Results of testing of subsets of features

\begin{tabular}{|c|c|c|c|c|}
\hline $\begin{array}{l}\text { Primary set of } \\
\text { features }\end{array}$ & $\begin{array}{l}\text { Features selected } \\
\text { applying SFS }\end{array}$ & $\begin{array}{l}\mathrm{CR} \\
(\%)\end{array}$ & $\begin{array}{c}\text { Spec. } \\
(\%)\end{array}$ & $\begin{array}{c}\text { Sens. } \\
(\%)\end{array}$ \\
\hline $\begin{array}{l}\text { Statistical } \\
\text { moments }\end{array}$ & $\begin{array}{l}\text { Variance, correlation, } \\
\text { homogeneity. }\end{array}$ & 60.00 & 56.66 & 64.00 \\
\hline $\begin{array}{l}\text { Gabor texture } \\
\text { features }\end{array}$ & $\begin{array}{l}\text { Standard deviation of } \\
\text { magnitude of the Gabor } \\
\text { transform coefficients } \\
\text { (wavelet scale } 0 \text { and } \\
\text { orientation } 0[6,9] \text { ). }\end{array}$ & 70.37 & 62.50 & 76.66 \\
\hline $\begin{array}{l}\text { MaZda texture } \\
\text { features }\end{array}$ & Contrast. & 72.72 & 76.00 & 70.00 \\
\hline $\begin{array}{l}\text { Geometrical } \\
\text { moments }\end{array}$ & $\begin{array}{l}\text { Moment of inertia, } \mathrm{Hu} 2 \text {, } \\
\text { Hu } 1 \text { moments. }\end{array}$ & 69.09 & 76.00 & 63.33 \\
\hline $\begin{array}{l}\text { SFS forward } \\
\text { (412 features) }\end{array}$ & $\begin{array}{l}\text { Difference variance, } \\
\text { moment of inertia. }\end{array}$ & 78.18 & 80.00 & 76.66 \\
\hline $\begin{array}{l}\text { SFS backward } \\
\text { ( } 412 \text { features) }\end{array}$ & $\begin{array}{l}\text { Moment of inertia, Haar } \\
\text { wavelet (scale - 2), } \\
\text { correlation. }\end{array}$ & 74.45 & 72.00 & 76.66 \\
\hline $\begin{array}{l}\text { SFS }(412 \\
\text { features }+ \text { SN) }\end{array}$ & $\begin{array}{l}\text { SN area, moment of } \\
\text { inertia }\end{array}$ & 87.27 & 83.33 & 92.00 \\
\hline
\end{tabular}

CR - classification rate, Spec. - specificity, Sens. - sensitivity.

\section{Discussion}

In the present research texture analysis of TCS images was performed with the aim to separate images obtained examining PD affected and healthy subjects. Various texture parameters were calculated and used for this classification task. The best classification results were obtained using the SFS method, when all calculated texture features were involved into analysis for selection of optimal subset of features. However obtained the classification results $(78.18 \%)$ are lower in comparison to result which was obtained using the measured size of SN area as a parameter for classification $(85.78 \%)$. A higher result $(87.27 \%)$ was obtained when the size of SN area was included into a primary set of features. Application of the SFS showed that moment of inertia could be a supplementing parameter and combination of these two parameters (size of SN area and moment of inertia) could increase the classification rate.

In summary it could be noticed that majority of texture parameters are representing various distributions of pixels in ROI. Therefore the discrimination power of these texture features is directly dependent on an image quality. Structural changes in the obtained images are frequently obscured by a big amount of speckle noise, so speckle denoising should be done in order to further increase the classification rate of TCS images.

Comparatively a small target group is a certain limitation of this study. This shortage was noticed during experiments: since groups for training and testing were separated randomly, the results of classification were slightly variable. More subjects should be examined in order to obtain more statistically reliable results of classification of TCS images.

\section{Acknowledgements}

This work is sponsored by Lithuanian Science Council in the frame of National science program „Chronic noninfectious diseases" project "Application of transcranial ultrasound for diagnostic of neurodegenerative diseases". No.: LIG-28/2010.

\section{References}

1. Berg D., Godau J., Walter U. Transcranial sonography in movement disorders. The Lancet Neurology. 2008. Vol. 7(11). P.1044-1055.

2. Berg D., Roggendorf W., Schroder U., et al. Echogenicity of the substantia nigra: association with increased iron content and marker for susceptibility to nigrostriatal injury. Arch. Neurol. 2002. Vol. 56. P. 999-1005.

3. Mehnert S., Reuter I., Schepp K., Maaser P., Stolz E., Kaps M. Transcranial sonography for diagnosis of parkinson's disease. BMC Neurology. 2010. Vol. 10(1). P. 1-9.

4. Kier C., Seidel G., Bregemann N., Hagenah J., Klein C., Aach T., Mertins A. Transcranial sonography as early indicator for genetic 
ISSN 1392-2114 ULTRAGARSAS (ULTRASOUND), Vol. 66, No. 3, 2011.

parkinson's disease. $4^{\text {th }}$ European Conference of IFMBE. 2009. P. 456-459.

5. Chen L., Hagenah J., and Mertins A. Texture Analysis Using Gabor filter Based on Transcranial Sonography Image. Proceedings of 2011 Bvm bildverarbeitung fur die medizin. 2011. P. 249-253.

6. Chen L., Seidel G., Mertins A. Multiple Feature Extraction for Early Parkinson Risk Assessment Based on Transcranial Sonography Image. Proceedings of 2010 IEEE 17th International Conference on Image Processing. 2010. P. 2277-2280.

7. Szczypinski P., Strzelecki M., Materka A., Klepaczko A. MaZda-A software package for image texture analysis, Computer Methods and Programs in Biomedicine. 2009. Vol. 94(1). P. 66-76.

8. Szczypinski P., Strzelecki M., Materka A. MaZda - a Software for Texture Analysis, Proc. of ISITC 2007, November 23-23, Republic of Korea. 2007. P. 245-249.

9. Manjunath B.S., Ma W.Y. Texture features for browsing and retrieval of image data. IEEE Transactions PAMI. 1996. Vol. 18(8). P. $837-842$

10. MaZda Feature Names List. http://www.eletel.p.lodz.pl/programy/mazda/download/FeaturerList.p df.

11. Haralick R. M., Shanmugam K., Dinstein I. Textural Features of Image Classification. IEEE Transactions on Systems, Man and Cybernetics. 1973. Vol. 3(6). P. 610-621.

12. Soh L., Tsatsoulis C. Texture Analysis of SAR Sea Ice Imagery Using Gray Level Co-Occurrence Matrices. IEEE Transactions on Geoscience and Remote Sensing. 1999. Vol. 37(2). P. $780-795$.

13. Clausi D A. An analysis of co-occurrence texture statistics as a function of grey level quantization. Canadian Journal of Remote Sensing. 2002. Vol. 28(1). P. 45-62.

14. Selecting Features for Classifying High-dimensional Data. Example of MATLAB Statistics Toolbox: http://www.mathworks.se/products/statistics/demos.html?file=/produ cts/demos/shipping/stats/cvsequentialfsdemo.html.

15. Gunn S.R. Support Vector Machines for Classification and Regression. Technical Report, university of Southampton. 1998. P. $5-16$.

16. Chapelle O., Haffner P., Vapnik V.N. Support vector machines for histogram-based image classification IEEE Transactions on Neural Networks. 1999. Vol. 10(5). P. 1055 - 1064.

A. Sakalauskas, A. Lukoševičius, K. Laučkaitė

Transkranijinės sonografijos vaizdų tekstūros analizė Parkinsono ligai diagnozuoti

Reziumé

Darbo tikslas - nustatyti transkranijinès sonografijos (TKS) vaizdų tekstūros analizès verte diagnozuojant Parkinsono liga (PL). Nagrinèjama galimybė skirti transkranijiniu ultragarsu (110 atvejų) užregistruotus vaizdus i dvi grupes: vaizdai gauti tiriant nesergančius neurodegeneracinėmis ligomis ir sergančiuosius, remiantis apskaičiuotais TKS vaizdu parametrais ir optimaliais parametru rinkiniais. Parametru rinkiniai sudaryti naudojantis nuoseklaus savybiu išrinkimo algoritmu. Išbandomi ankstesnių tyrèjų šiam klasifikavimo uždaviniui pasiūlyti parametrai ir daugiau kaip 100 naujų parametrų, apibūdinančiu dominančią sriti (vidurines smegenis) vaizde. Klasifikavimo efektyvumas ivertinamas apskaičiavus klasifikavimo klaidu skaičiu, jautrumą ir specifiškuma, kada oficiali klinikinè diagnozè laikoma teisinguoju rezultatu. Klasifikavimo tikslumas lyginamas su rezultatu, gautu atlikus klasifikaciją pagal TKS vaizde išmatuoto juodosios medžiagos ploto dydžio slenkstinę vertę.

Pateikta spaudai 20110920 